\title{
CULTURAL CONTENT IN ENGLISH TEXTBOOK FOR DEAF STUDENTS AT DISABLE SENIOR HIGH SCHOOL
}

\author{
Nor Fitriansyah, Masni Usman, Surono \\ Universitas Ahmad Dahlan (UAD), DIY Yogyakarta, Indonesia \\ E-mail: nfitriansyah20@gmail.com
}

Received: 2021-11-10

Accepted: 2021-11-27

\begin{abstract}
This study explores the cultural content represented in the English Textbook used by the deaf students at disable senior high school or SMALB (Tuna Rungu). This book was published by Kemendikbud of Indonesia in 2016. This study was categorized as Descriptive qualitative research. The method used in this study is textbook content analysis. To collect the data, the writers selected the text, pictures and activities presented in each unit of the textbooks. Meanwhile, to analyze the data, the writers adapted two different frameworks. The first framework was used to explore what cultures are represented in the textbook (types of culture). The second framework was used to explore how the cultures were represented in the textbook (sense of culture). There are 157 cultural contents found in the Tunarungu Bahasa Inggris SMALB Grade XI 2016 book. By Type of Culture, the 157 cultural contents were divided into 60 Source Culture, 94 Target Culture and 3 International culture. Meanwhile, in terms of Sense of Culture, the 157 cultural contents were divided into 5 Aesthetic Senses, 3 Sociological Senses, 59 Semantic Senses and 90 Pragmatic Senses.
\end{abstract}

Keywords: Textbook, Cultural Content, Cultural Sense

\section{Introduction}

Each country has different culture. It is important to be considerate about the language production context so the recipient will not misunderstand it. Say for example, Native English speaker would refer the word "Lunch" to pizza or hamburger. On the other hand, native Indonesian speaker would refer that word into rice. In line with the statement, Jiang (2000) states that when people use the same language forms, it might refer to different thing based on their own culture. Therefore, that is why learning or teaching a language, at the same time is influenced by the culture.

As we know, the existences of culture help the learner to interpret their language in their real life. It is important for the learners to realize that learning culture as a part of language learning. They need to be aware that cultural understanding is the core for them in acquiring the language. The existence of cultural content can be seen from textbooks or course books, for example ELT textbooks. Textbook is the most accessible and universal element in ELT process. In line with the statement, Cortazzi and Jin (1999) state that textbook is believed as the main means of linguistic and cultural knowledge of the target language in EFL classes. ELT textbooks not only provide the students input such as texts, activities or explanation that contains grammatical or structural content but also cultural content of the target language. Textbook is expected to provide the cultural content which 
the learner can learn through it and improve their intelligence. In English language teaching, usually, English teacher uses textbook as source material to support their teaching. It can be a guide for teacher to instruct the students. Since there are many kinds of ELT textbooks, it is important for English teacher to select the textbooks properly which do not only consist of text or activity but also reflect the cultural content of the target language. So, one of the way in selecting the ELT textbooks is doing a cultural content analysis. Cultural content analysis needs to be conducted in order to see the appropriateness of the ELT textbook.

Usually, there are two kinds of ELT textbooks divided by the users namely ELT textbooks for Regular students and ELT Textbooks for Disable students. Both of the textbooks used in regular and disable schools are pretty similar. Both textbooks provide enough material such as texts, pictures and kinds of activities for learning, but there are some unique points from the ELT textbooks used by deaf students at disable senior high school. To begin with, the textbook uses more text based approach. It is because the language aspect such as vocabulary, pronunciation, word stress, grammar, and aspects others are things that really need time and processes that are not few and may not be easy to understand for the deaf student because English has many differences in writing, pronunciation, and meaning. Through this approach, learning refers to the function of language and its use, which is a unity meaning both orally, and in writing. The material in this book can provide knowledge and skills to deaf students in everyday life. Existing materials are more functional and useful for deaf students in everyday life. Furthermore, the ELT textbooks contain only few important topics because the students take a long time for mastering each topic. In conclusion, the textbook is interestingly designed with various pictures and colors so that the student will enjoy learning.

In Indonesia, some previous studies related to cultural content analysis of ELT textbook have been conducted by some researchers, such as, Faris (2014), , Mayangsari, Nurkamto, \& Supriadi (2018), Lekawael, Emzir, \& Rafli (2018) and etc. All of the studies above have shown about the cultural content in many kinds of ELT textbooks from different authors in Indonesia. Unfortunately, all the studies before were focused on cultural content analysis of Regular ELT textbooks and none of them was conducted regarding to the cultural content analysis of ELT textbook for deaf students at disable senior high school or SMALB (Tuna Rungu).

To fulfill the gap above, the writers are interested in carrying out a study about cultural content analysis of ELT textbook for deaf students at disable senior high school or SMALB (Tuna Rungu). In this study, the writers choose an English textbook for secondary student. The goals of this study are to investigate about what types of culture represented and how the culture represented in the English textbooks.

\section{Literature Review}

Textbook is one of the main sources used in learning a language. Textbooks have a very crucial role in education process especially English language teaching (Aliakbari, 2005). It means that choosing the appropriate textbook for the learners is really needed. One of the important things to be considered in choosing the ELT textbooks is the cultural content inside. Teaching learners about cultural aspects may be effectively applied through textbook because textbooks can offer many advantages both for teacher and student when its' being used in the class. In other words, an English teacher might use the ELT textbook as the authentic material in teaching both language and culture. Regarding culture-related teaching materials and textbooks in English classroom, Cortazzi and Jin (1999) divided the types of 
cultural content of the materials in English textbook into three types. They are source culture, the target culture, and the international culture.

The first is the source culture materials which refer to materials presenting language learners own culture. In this case, the source culture refers to Indonesian cultures. Indonesia is divided into many ethnics such as Malay, Javanese, Balinese, and other ethnics. The presented aspects of cultures could be the stories about Indonesian legend, pictures of Indonesian people, and other aspects, for instance, the story about RA Kartini (Java Heroine). It reflects the Javanese local culture. It is aimed to make students familiar with the local culture and promoting the local culture to be more popular among students. The second is the target culture materials, which refer to materials presenting the culture of English native speakers' countries. Target culture belongs to the inner circles countries such as USA, UK, New Zealand and Canada (Kacru, 1996). The textbooks of this category are the most popular instruction materials in the EFL context. The aim of the target culture materials is usually exposing users to the cultural contexts of the target language. The last one is the International culture materials, which refer to materials presenting a wide variety of culture in countries around the world where English is not used as first language but as an international language such as in China, Brazil, Korea and other countries. The aims of the international culture materials are raising user intercultural awareness and making users familiar with various socio-cultural contexts.

Furthermore, culture in the textbook can also be categorized based on the four senses of culture framework proposed by Adaskou, Britten \& Fahsi (1990). This framework covers the general categorizations of culture which are the totalist view and the mentalist view, and the big - $\mathrm{C}$ culture and the small -c culture. The culture with the capital $\mathrm{C}$ refers to the media, the cinema, music and other literature aspects, while the culture with small c refers to the organization and nature of family, friends, and institutions. The culture within this framework is categorized into four senses: the aesthetic sense, the sociological sense, the pragmatics sense and the semantic sense. The aesthetic sense of culture refers to the media, the cinema, music, and above all literature-research (literary researches) which are often to be one of the main reasons for language teaching. In the textbook, this sense of culture is commonly found in the textbooks in terms of the information about cinema, theater, song, concert and other contents of big $-\mathrm{C}$.

The sociological sense of culture refers to the organization and nature of family, home life, of interpersonal relation, material condition, work and leisure, custom, and institution. The sociological sense of culture can be perceived as the bottom of an iceberg or the small -c of culture. This type is also commonly used to represent the relationship between family members, institutions and friends. This sense aims to support the interpersonal communication between people around the learners for instance, the relationship between two friends. The semantic sense of culture refers to the conceptual system embodied in the language and conditioning all our perceptions and our thought process. Many semantics areas (e.g., food, clothes, and institutions) are culturally distinctive because they relate to a particular way of life- that is to our sociological sense of culture, so these cultural features like culture in one sociological sense may differ for English from one English-speaking country to another. This type of sense is uncommonly stated in the textbook.

The last, the pragmatic sense (or sociolinguistic) refers to the background knowledge, social skills, and paralinguistic skills. It includes: 1 . the ability to use appropriate exponents of the various communicative functions, 2 . the ability to use appropriate intonation patterns, 3 . the ability to conform to norms and politeness, which are different from the learners, 
Cultural Content in English Textbook for Deaf Students at Disable Senior High School, Nor Fitriansyah, Masni Usman, Surono

culture, including taboo avoidance, awareness of conventions governing interpersonal relations questions of status, obligation, license, which are different from learners, culture. 4. familiarity with the main rhetorical conventions in different written genres e.g., different types of letters and messages, form-filling, advertisements. In addition, some researchers prove that this sense is commonly represented in the English textbooks, such as in (Silvia, 2014). This type usually appears in terms of grammars and speech acts.

Based on the explanation above, the writers will adapt these two frameworks from Cortazzi and Jin (1999) and Adaskou, Britten \& Fahsi (1990) in order to investigate what cultures are represented in and how the culture are represented in the English textbook of secondary student at Special Education School or SMALB (Tuna Rungu) published by Kemendikbud. The findings can be used to determine whether the book is appropriate or not to be used. Furthermore, the findings also might be used for English textbook development especially in terms of cultural content.

\section{Research Method}

This study is categorized as descriptive qualitative research, which is a textbook content analysis. In this study, the main source of the data taken from the English textbook that used by the secondary student at Special Education School or SMALB (Tuna Rungu) published by Kemendikbud. The data were collected by selecting the reading passages, dialogues, pictures and activities presented in each unit of the textbooks, determining the unit to be coded and developing content categories. One of the ways to collect the data is setting up a check-list format based on the framework chosen by the writer. First framework from Cortazzi and Jin (1999) will be used to reveal what cultures are represented in the English textbook. The second framework from Adaskou, Britten and Fahsi (1990) used to reveal how cultures are represented in the English textbook.

There are two main steps in analyzing the data based on these two frameworks above. First, in order to reveal what cultures are represented in the textbooks, the writers used the framework from Cortazzi and Jin (1999) and categorized the culture material into three types which are source culture, target culture, and international culture based on the reading passages, dialogues, pictures and activities presented in each unit in the textbooks. Second, by using the framework Adaskou, Britten, and Fahsi, (1990), the writers will reveal how cultures are represented in the textbooks by categorized them into Aesthetic sense, Sociological sense, Pragmatic sense and Semantic sense. Then, the frequency of the data categorized was converted into percentages. The percentages were compared and analyzed to investigate what cultures occurred most frequently and how the cultures were represented most frequently in the textbooks. The findings were presented in forms of tables and graphs. Then, the results of the study will be discussed qualitatively.

\section{Results and Discussion}

After doing cultural content analysis of the English textbook entitled "Tunarungu Bahasa Inggris SMALB Grade XI 2016", the writers summed up the findings as follows:

\begin{tabular}{|c|c|}
\hline \multicolumn{2}{|c|}{$\begin{array}{c}\text { English textbook for secondary student of senior high school entitled } \\
\text { "Tunarungu Bahasa Inggris SMALB Grade XI 2016" by Endah Dwi Astuti }\end{array}$} \\
\hline Chapter & Topic \\
\hline 1 & What did you do yesterday? \\
\hline
\end{tabular}




\begin{tabular}{|c|c|}
\hline 2 & What happend to your arm, Haidar? \\
\hline 3 & A Wonderful trip \\
\hline 4 & I'm going to make a cake \\
\hline 5 & Dear Brina \\
\hline
\end{tabular}

Table 1. The Detail Information of Textbook.

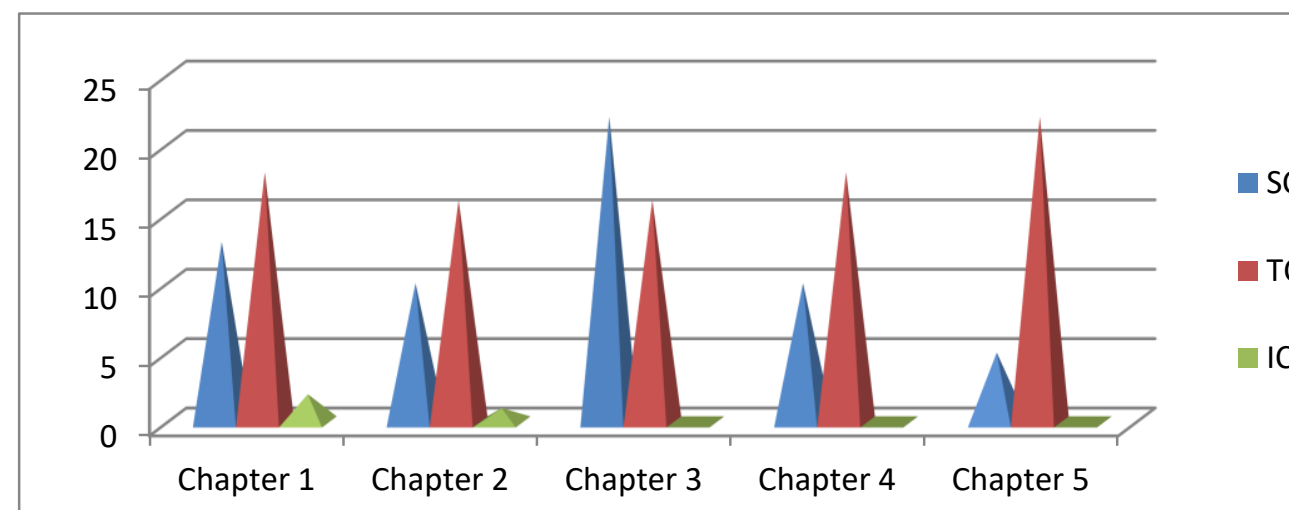

Chart 1. Types and numbers of Culture in the English Textbook by Each Chapter

\begin{tabular}{|c|c|c|c|}
\hline & \multicolumn{3}{|c|}{ Types of Culture } \\
\cline { 2 - 4 } & Source Culture & Target Culture & International Culture \\
\hline Chapter $\mathbf{1}$ & 13 & 18 & 2 \\
\hline Chapter $\mathbf{2}$ & 10 & 16 & 1 \\
\hline Chapter 3 & 22 & 16 & 0 \\
\hline Chapter $\mathbf{4}$ & 10 & 18 & 0 \\
\hline Chapter 5 & 5 & 22 & 0 \\
\hline \multirow{2}{*}{ Total } & 60 & 94 & 3 \\
\cline { 2 - 4 } & \multicolumn{3}{|c|}{$\mathbf{1 5 7}$} \\
\hline
\end{tabular}

Table 2. Types and numbers of Culture in the English Textbook by Each Chapter

\subsection{Types of Cultures Represented in the Textbook}

Based on the chart and table shown above, it can be seen that not the entire chapter from the book contains all of the types of the cultures. The complete explanations are as follows:

\section{a. Source Culture}

Based on the results from the table above, it can be seen that all five chapters in this book present the source culture. The first sources culture presented in the book are 24 different names of Indonesian people, those names below are names that commonly used by Indonesian people. Therefore, those names are categorized as source culture in this book.

\begin{tabular}{|c|c|c|}
\hline No & Items & Page \\
\hline 1 & Raka & $p .14$ \\
\hline 2 & Rizal & $p .14$ \\
\hline 3 & Asep & $p .16 \& 68$ \\
\hline 4 & Nyoman & $p .16$ \\
\hline 5 & Andi & $p .18,66,67 \& 89$ \\
\hline 6 & Eko & $p .21$ \\
\hline
\end{tabular}


Cultural Content in English Textbook for Deaf Students at Disable Senior High School, Nor Fitriansyah, Masni Usman, Surono

\begin{tabular}{|c|c|c|}
\hline 7 & Haidar & p. $23 \& 36$ \\
\hline 8 & Dafa & p. $26 \& 36$ \\
\hline 9 & Toni & p. 32 \\
\hline 10 & Joko & p. 32 \\
\hline 11 & Dika & p. 40 \\
\hline 12 & Dimas & p. 41 \\
\hline 13 & Tono & p. 41 \\
\hline 14 & Sinta & p. 41 \\
\hline 15 & Tuti & p. 45 \\
\hline 16 & Yusmarni & p. $65,67, \& 68$ \\
\hline 17 & Putu & p. 67 \\
\hline 18 & Yuswono & p. $66 \& 68$ \\
\hline 19 & Isna & p. 66 \\
\hline 20 & Komang & p. 68 \\
\hline 21 & Ikhsan & p. $76,104,105,106, \& 110$ \\
\hline 22 & Dewi & p. 77 \\
\hline 23 & Wulan & p. $98 \& 102$ \\
\hline 24 & Wawan & p. $104,105,106, \& 110$ \\
\hline
\end{tabular}

Table 3. Different names of Indonesian people

The second source culture is nine different cities/location, those cities below are located in the territory of of Indonesia, therefore those cities are included in the source culture category.

\begin{tabular}{|c|c|c|}
\hline No & Items & Page \\
\hline 1 & Wonogiri & p. 18, 93, 97, 99, 100, 101, 103, \& 112 \\
\hline 2 & Jakarta & p. 20,45, 46, 47, 49, 93, 97, 99, 100, 101, 103, 104 \& 112 \\
\hline 3 & Yogyakarta & p. 45, 46, 47, \& 49 \\
\hline 4 & Solo & p. 45, 46, 47, \& 49 \\
\hline 5 & Magelang & $p .48$ \\
\hline 6 & kota Gede & $p .49$ \\
\hline 7 & Bali & $p .51$ \\
\hline 8 & Cibubur & $p .104$ \\
\hline 9 & Surabaya & $p .106$ \\
\hline
\end{tabular}

Table 4. Different cities in Indonesia

The third source culture is fifteen places. Meanwhile, those places below are very familiar to Indonesian people, which have become a habit for Indonesians to visit places such as markets and schools and tourist attractions, such as beaches or mountains. Therefore, this place is categorized as source culture.

\begin{tabular}{|c|c|c|}
\hline No & Items & Page \\
\hline 1 & Studio 21 & $p .16$ \\
\hline 2 & Malioboro & $p .43,45,46,47,48 \& 49$ \\
\hline 3 & Candi Borobudur & $p .43,45,46,47,48 \& 49$ \\
\hline 4 & Pesona Alam Tawangmangu & p. 43, 45, 46, 47, 48 \& 49 \\
\hline
\end{tabular}




\begin{tabular}{|c|c|c|}
\hline 5 & Candi Prambanan & p. $43,45,46,47,48 \& 49$ \\
\hline 6 & Sangiran Museum & p. $43,45,46,47,48 \& 49$ \\
\hline 7 & Tanah Lot & p. 51, $53 \& 54$ \\
\hline 8 & Kuta Beach & p. $51,53 \& 54$ \\
\hline 9 & Sanur Beach & p. $51,53 \& 54$ \\
\hline 10 & Tampak Siring & p. $51,53 \& 54$ \\
\hline 11 & Bedugul Lake & p. $51,53 \& 54$ \\
\hline 12 & Sukowati Market & p. $51,53 \& 54$ \\
\hline 13 & SLB Hari Mulia & p. 60 \\
\hline 14 & Gunung Lawu & p. 89 \\
\hline 15 & Ragunan Zoo & p. $93,97,99,100,101,103, \& 112$ \\
\hline
\end{tabular}

Table 5. Different places in Indonesia

The fourth source culture is four kinds of food. These foods are familiar and typical foods that can be found in Indonesia.

\begin{tabular}{|c|c|c|}
\hline No & Items & Page \\
\hline 1 & Sate Kelinci & p. 60 \\
\hline 2 & Jagung Bakar & p. 60 \\
\hline 3 & Fried noodle & p. 67 \\
\hline 4 & Rice & p. 68 \\
\hline
\end{tabular}

Table 6. Different food in Indonesia

The fifth source culture is two kinds of arts, Batik and Tari Barong known as kinds of local arts from Indonesia. Batik is a cloth art almost all regions in Indonesia have beautiful and different Batik motifs, while the Tari barong is a local dance from Bali.

\begin{tabular}{|c|c|c|}
\hline No & Items & Page \\
\hline 1 & Batik & $p .46,47, \& 49$ \\
\hline 2 & Tari Barong & p. 51, 53 \& 54 \\
\hline 3 & Javanese Traditional Costume & $p .5$ \\
\hline
\end{tabular}

Table 7. Different arts in Indonesia

The last source culture is four local activities. The local activities in this book are some of the activities that are familiar to Indonesian people.

\begin{tabular}{|c|c|c|}
\hline No & Items & Page \\
\hline 1 & Market activity & $p .5$ \\
\hline 2 & Indonesian cooking style & p. 5 \\
\hline 3 & Indonesian school setting & p. 3, 4, 5, \& 6 \\
\hline 4 & Motorcycle with Solo's license number style & p. 38 \& 78 \\
\hline
\end{tabular}

Table 8. Local activities

In addition, some pictures are used to show how books represent source culture like places and activities, the pictures can be seen below: 
Cultural Content in English Textbook for Deaf Students at Disable Senior High School, Nor Fitriansyah, Masni Usman, Surono

\section{A WONDERFUL TRIP}

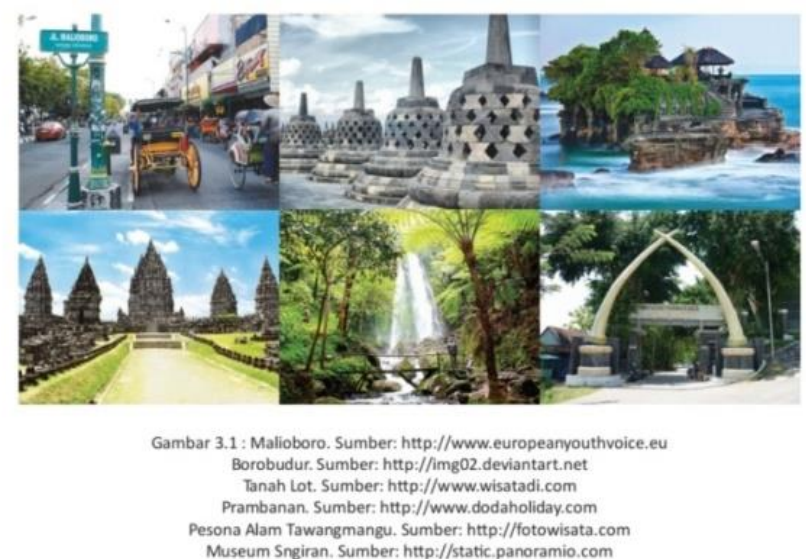

Picture 1. (Source Culture - Places)

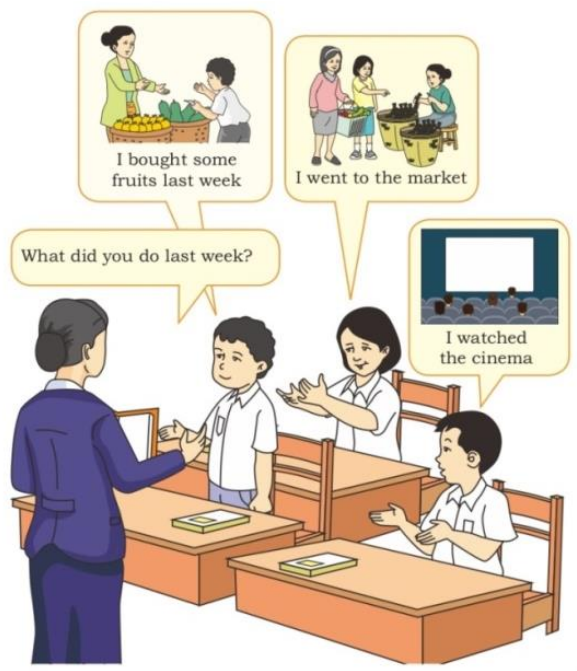

Picture 2. (Source Culture - Javanese Traitional Costume, Market Activity \& Indonesian Class Setting)

The pictures above are examples of source cultures attached in the book, such as school setting, market activity, and Javanese traditional costume. There are also some pictures of places in Indonesia, such as Borobudur Temple and Tanah Lot Bali.

\section{b. Target Culture}

The results from the table below show that all five chapters in this book present the target culture.

\begin{tabular}{|c|c|c|}
\hline No & Items & Page \\
\hline 1 & Mariah Carey (name) & $p .70 \& 71$ \\
\hline 2 & Maywood (name) & $p .94 \& 95$ \\
\hline 3 & Hero (song) & $p .70$ \\
\hline 4 & Mother How are You Today (song) & $p .94 \& 95$ \\
\hline 5 & $\begin{array}{c}\text { Expression of asking and giving information about } \\
\text { daily activities (grammar) }\end{array}$ & 18 times. $p .7-21$ \\
\hline 6 & $\begin{array}{c}\text { Expression of asking and giving information about } \\
\text { daily activities in the past (grammar) }\end{array}$ & 16 times. p. 25-42 \\
\hline
\end{tabular}


Language Literacy: Journal of Linguistics, Literature and Language Teaching

Volume 5, Number 2, pp: 453-464, December 2021

e-ISSN: 2580-9962 | p-ISSN: 2580-8672

DOI: $10.30743 /$ II.v5i2.4529

\begin{tabular}{|c|c|c|}
\hline 7 & $\begin{array}{c}\text { Expression of giving information about experience } \\
\text { (grammar) }\end{array}$ & 16 times. $p .43-62$ \\
\hline 8 & $\begin{array}{c}\text { Expression of asking and giving information about } \\
\text { one's intention (grammar) }\end{array}$ & 15 times. $p .63-91$ \\
\hline 9 & $\begin{array}{c}\text { Expression of giving information about song lyrics } \\
\text { (grammar) }\end{array}$ & 3 times. $p .63-91$ \\
\hline 10 & How to write personal later (grammar) & 19 times. p. 92-114 \\
\hline 11 & Understand the lesson of a song (grammar) & 3 times. p. $92-114$ \\
\hline
\end{tabular}

Table 9. Target Culture Items

This book is indeed dominated by the target culture. Here are some examples of the target culture material contained in the book, which can be seen from the pictures below:

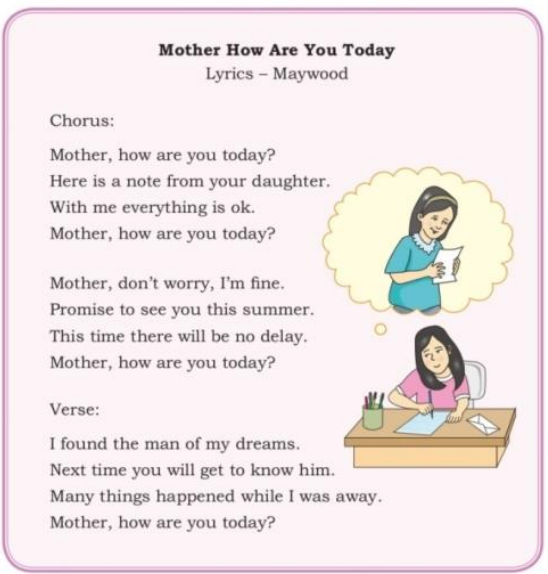

Picture 3. (Target Culture - Mother How Are You Today a song by Maywood)

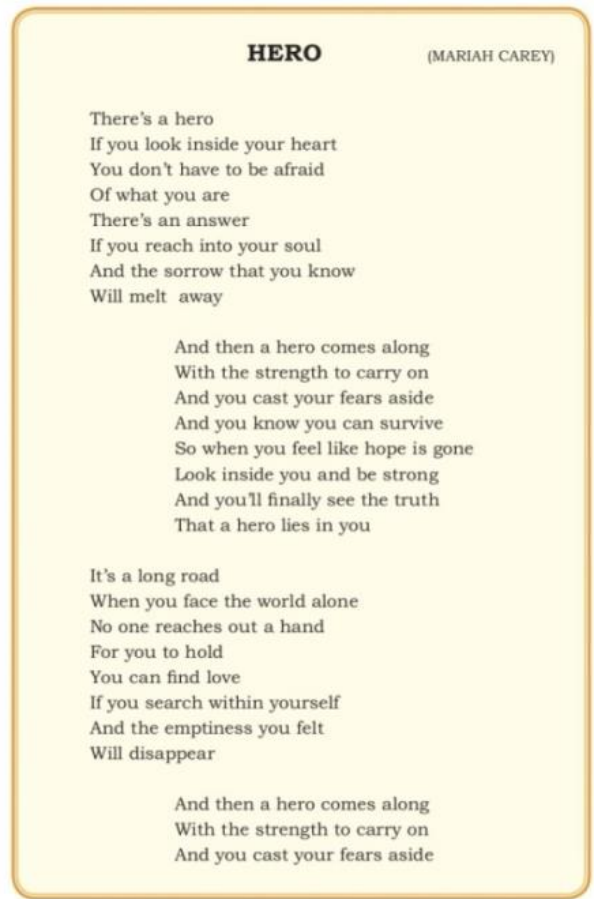

Picture 4. (Target Culture -Hero a song by Mariah Carey) 
Cultural Content in English Textbook for Deaf Students at Disable Senior High School, Nor Fitriansyah, Masni Usman, Surono

1. We use will when we decided to do something at the time of speaking.

Example: I will have an ice tea, please

2. The declarative form of future tense is :

They

You + will + do the homework

$\mathrm{He}$

She

It

3. The negative form of future tense is :

We

They

You + will + not + do the homework

She

It

The negative form of will is won't

4. The interrogative form of future tense is:

will + You + do the homework?

$\mathrm{He}$

She

Picture 5. (Target Culture - One of grammar material in the book)

\section{c. International Culture}

There are very few target cultures found in this book, and those are only found in chapter 1 and chapter 2 . There are only two international culture presented in the book in the chapter 1 and chapter 2, the first one are 2 kinds of food, sphagetti (p. $6 \& 10$ ) and Pizza (p. 37). The last international culture is the picture of a Big Ben as a tourism sight (p. 1). It can be seen below that some pictures represent international culture:

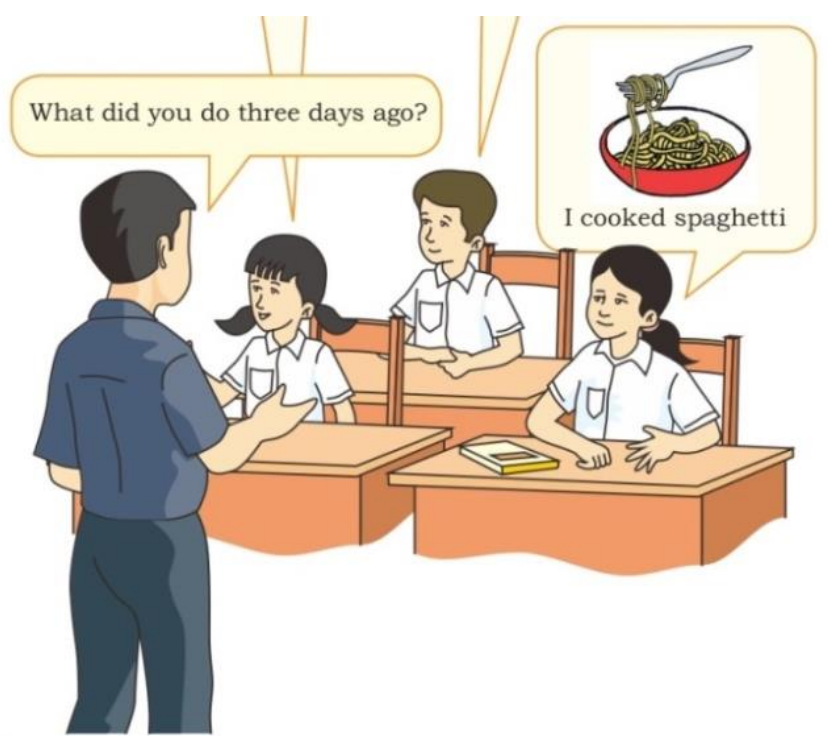

Picture 6. (International Culture - Kinds of Food - Spaghetti) 


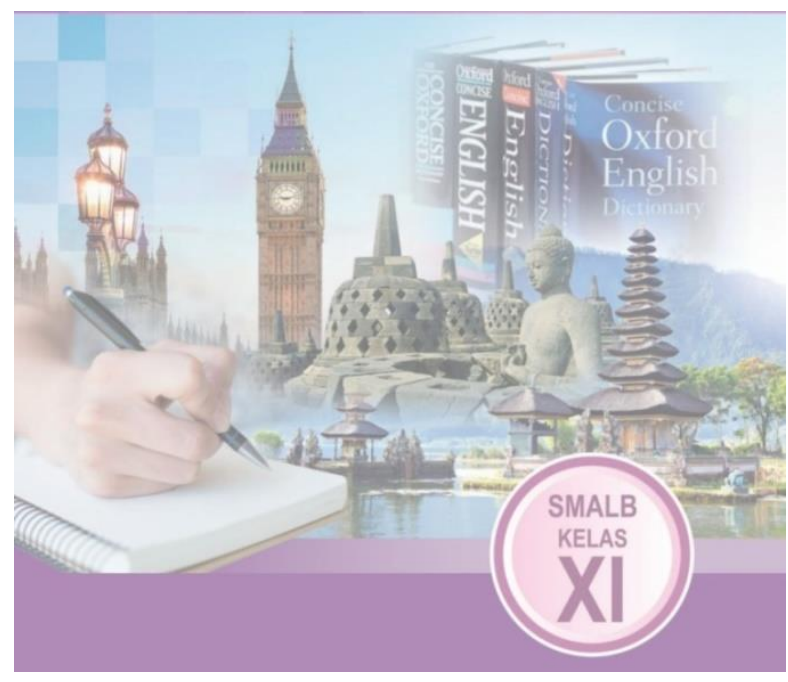

Picture 7. (Target Culture - Touris Attraction - Big Ben)

\subsection{How Sense of Culture represented in the Textbook}

All senses of cultures were represented: Aesthetic Sense, Sociological Sense Semantic Sense and Pragmatic Sense. The detailed explanation can be seen in the table below:

\begin{tabular}{|c|c|c|c|c|c|}
\hline Category of Culture & \begin{tabular}{|c|} 
The \\
Aesthetic \\
Sense \\
\end{tabular} & $\begin{array}{c}\text { The } \\
\text { Sociological } \\
\text { Sense }\end{array}$ & $\begin{array}{l}\text { The } \\
\text { Semantic } \\
\text { Sense }\end{array}$ & $\begin{array}{c}\text { The Sense } \\
\text { Pragmatic } \\
\text { Sense }\end{array}$ & TOTAL \\
\hline The Source Culture & 3 & 3 & 54 & 0 & $\begin{array}{c}60 \\
(38.2 \%)\end{array}$ \\
\hline The Target Culture & 2 & 0 & 2 & 90 & $\begin{array}{c}94 \\
(59.8 \%)\end{array}$ \\
\hline $\begin{array}{c}\text { The International } \\
\text { Culture }\end{array}$ & 0 & 0 & 3 & 0 & $\begin{array}{c}3 \\
(1.9 \%)\end{array}$ \\
\hline TOTAL & $\begin{array}{c}5 \\
(3.1 \%)\end{array}$ & $\begin{array}{c}3 \\
(1.9 \%)\end{array}$ & $\begin{array}{c}59 \\
(37.5 \%)\end{array}$ & $\begin{array}{c}90 \\
(57.3 \%)\end{array}$ & $\begin{array}{c}157 \\
(100 \%)\end{array}$ \\
\hline
\end{tabular}

Table 10. The Frequency of Cultural Contents - Types and Sense of Culture in the Textbook

We can see in the table above there are 157 senses of culture presented in this book. Aesthetic sense was presented 5 times with a percentage of $3.1 \%$. The aesthetic sense in this book is found in the Source Culture section 3 times in the form of (Arts: Barong traditional dance, Javanese traditional clothes and Batik), and there are 2 aesthetic senses in Target culture in the form of Song: Hero - Mariah Carey and Mother How are You Today Maywood. On the other hand, there is no aesthetic sense found in International culture.

There are only 3 sociological senses found in this book with a percentage of $1.9 \%$. All of the sociological senses in this book are found in the Source culture section (Activities in the market, A school setting and Indonesian cooking styles), which means that there is no sociological sense found in the Target culture and International culture.

The third sense of culture is Semantic sense. There are 59 Semantic senses with a percentage of $37.5 \%$ found in this book. There are 54 Semantic senses found in Source culture such as (Names of Indonesians: Komang, Andi Nyoman etc., City: Jakarta, Yogya, 
Cultural Content in English Textbook for Deaf Students at Disable Senior High School, Nor Fitriansyah, Masni Usman, Surono

solo etc. as well as Food: Nasi Goreng and Mie Goreng). Then, there are 2 Semantic senses in the Target culture in the form of (Name: Mariah and Maywood), and there are 3 Semantic senses in International culture in the form of (Food: Spaghetti and Pizza \& Place: Big Ben)

The last sense of culture is pragmatic sense. There are 90 forms of Pragmatic sense found in this book with a percentage of $57.3 \%$, which makes Pragmatic sense the most sense of culture found in this book. All of the Pragmatic senses in this book are found in the Target culture (Expression of asking and giving information about daily activities, Expression of giving information about experience, How to write personal later, Expression of giving information and understand the meaning of a song lyrics, etc)

\section{Conclusion}

In conclusion, there are 157 cultural contents found in the Tunarungu Bahasa Inggris SMALB Grade XI 2016 book. By Type of Culture, the 157 cultural contents are divided into 60 forms of Source Culture, 94 Target Culture and 3 International culture. The most Type of Culture frequently found is Source Culture such as the names of Indonesian people, cities in Indonesia and several places in Indonesia, while for the Target Culture, grammar and learning materials are the most frequently found contents, and International Culture is the least common types of culture. Meanwhile, in terms of Sense of Culture, the 157 cultural contents are divided into 5 Aesthetic Senses, 3 Sociological Senses, 59 Semantic Senses and 90 Pragmatic Senses.

\section{References}

Adaskou, K., Britten, D., \& Fahsi, B. (1990). Design Decisions on the Cultural Content of a Secondary English Course For Morrocco. ELT Journal, 3-10.

Aliakbari, M. (2005). The Place of Culture in the Iranian ELT Textbooks in High School Level. Journal of Pan-Pacific Association of Applied Linguistics, 163-179.

Cortazzi, M., \& Jin, L. (1999). Cultural Mirrors: Materials and Methods in the EFL Classroom. Culture in teh Second Language Teaching and Learning, 149-176.

Faris, I. (2014). Cultural content analysis of an English textbook for seniorhigh school grade three in Cianjur, West Java. ournal of English and Education, 14-25.

Jiang, W. (2000). The Relationship between Culture and Language. ELT Journal, 328-334.

Kacru, B. (1996). World Englishes: agony and ectasy. Journal of AestheticEducation, 136-138.

Lekawael, R., Emzir, \& Rafli, Z. (2018). The Cultural Values in Texts of English Coursebooks for Junior High School in Ambon, Moluccas Indonesia. Advances in Language and Literary Studies, 24-30.

Mayangsari, L., Nurkamto, J., \& Supriadi, S. (2018). Cultural Content: An Analysis of EFL Textbook in Indonesia. International Journal of Scientific and Research Publications.

Silvia, A. (2014). Cultural content in English textbooks used at MadrasahTsanawiyah Negeri in DKI Jakarta. Jakarta: UIN Syarif Hidayatullah Jakarta, Indonesia. 